\title{
Haliç Kıyısında Tarihi bir Sanayi Yapisı: Unkapanı Değirmeni
}

Yrd. Doç. Dr. Füsun Seçer Kariptaş

Haliç Üniversitesi, Mimarlık Fakültesi

\section{Giriş}

Endüstri yapılarının öneminin fark edilmesi, onların bir miras olarak algılanmalarıyla mümkün olmuştur. Mirasın zaman içerisinde, kültürel anlamdaki genişleme, "endüstri mirası" kavramını ortaya çıkarmıştır. Bu kavramın doğuşuyla birlikte sanayi yapılarının kültürel kimlik açısından taşıdı̆̆ 1 öneme dikkat çekilmiş, teknolojinin gelişmesiyle her geçen gün yetersiz kalan üretim teknikleri nedeniyle, endüstri yapılarının terk edilmeleri karşısında gösterilen tepkiler bu alandaki koruma çalışmalarını tetiklemiştir.

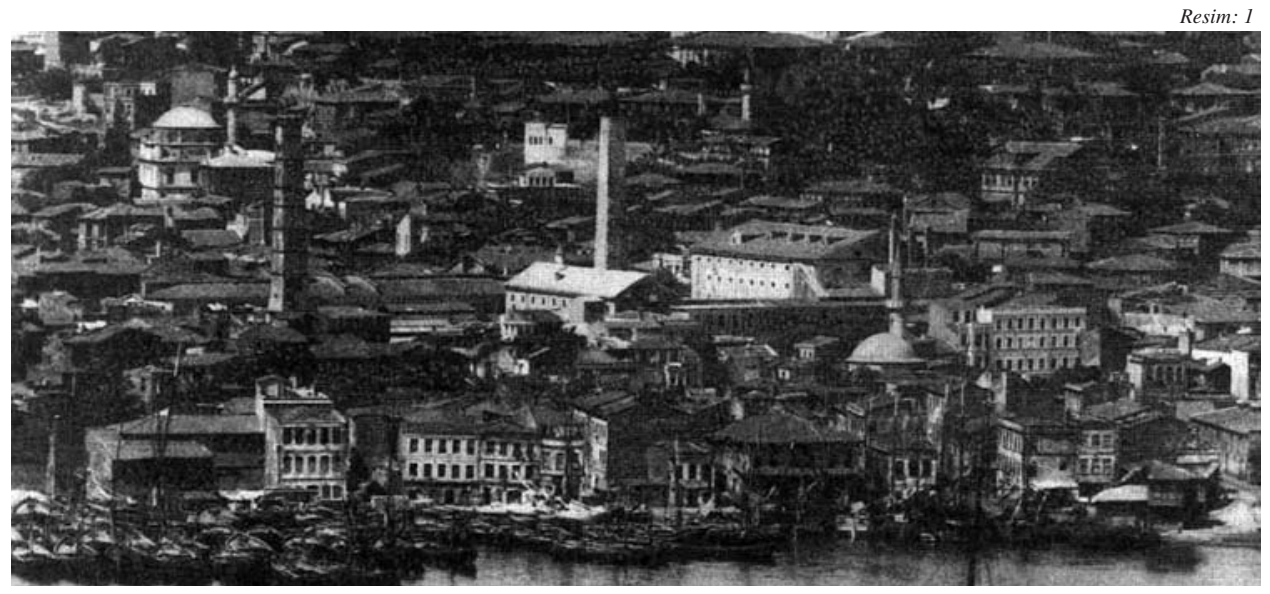

Batılılaşma döneminde inşa edilen endüstri yapıları, o dönemin teknolojisini ve ekonomik düzenini aktarması, toplumun yaşadığı belirli bir süreci yansıtması açısından büyük bir öneme sahiptir. Diğer anıtsal bina türleri kadar korunmamış olan endüstri yapıları zamanla fonksiyonunu yitirmiş, boş ve bakımsız kalarak hızla tahrip olmuşlardır. Bugün harap ve bakımsız olan endüstri yapılarının, zaman içinde hasar görmesini önlemek ve mümkün olduğunca korumaya çalışmak gerekmektedir.

Özet:

Dünyada endüstri arkeolojisi kavramı, 20.yüzyılın ikinci yarısında ortaya çıkan ve mekanik araçlarla ve düzeneklerle mal veya hizmet üretme etkinliğini ve bu amaçla oluşturulmuş özgün mimariyi bütünsel olarak kendisine konu alan bir bilimsel

disiplindir. Endüstri arkeolojisi denilince yalnızca endüstri çağında üretim-imalat yapılan yapıları ve aletlerini çağrıştırsa da, aslında tüm dönemlerdeki donanımlar anlaşılmaktadır. Endüstri arkeolojisi kapsamındaki tüm kaynaklar, endüstri mirasını oluşturur. Bu mirasın gelecek kuşaklara aktarılabilmesi, yapıları uygun bir işlevle kent hayatına kazandırmanın yanı sıra, özgün kimliklerini de korumayla sağlanabilir. İstanbul'da bulunan endüstri miraslarından biri de Unkapanı Değirmeni'dir. Bu yazıda endüstri yapılarının korunarak yeniden kullanımı anlayışıyla, Unkapanı Değirmeni hakkında bilgi verilmiştir. Bu nedenle öncelikle yapının tarihçesi, konum ve çevre özelliklerinden bahsedilmiş, daha sonra yapıldığı 1870 yılından günümüze kadar geçirmiș olduğu değișim mimari açıdan irdelenerek, elde edilen bulgular plan ve cephe çizimleri ile desteklenmiş; sonuç bölümünde de yapının yaşatılması için çözüm önerisinde bulunulmuştur.

54 Sayı 7, Mayıs 2009 


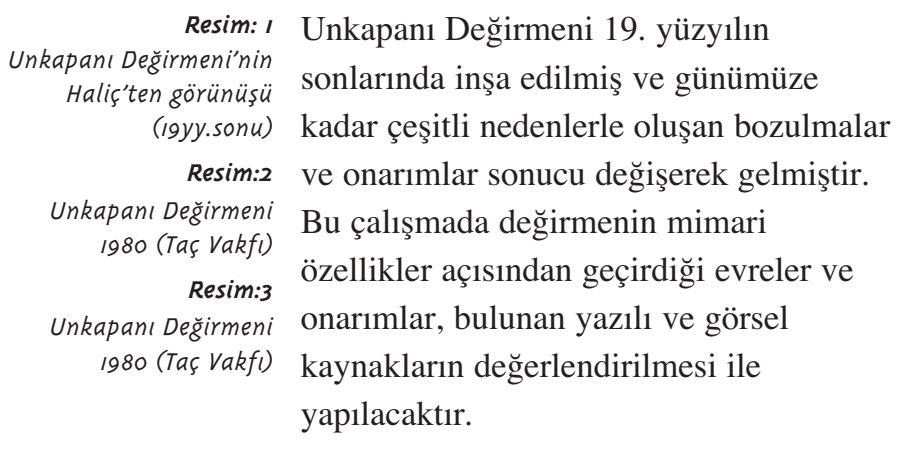

\section{Yapının tarihçesi}

Unkapanı semti adını "un” ve Osmanlılar döneminde kullanılan bir çeşit tartı aleti olan, toptan satış yapılan yer anlamına da gelen "kapan" kelimelerinden almıştır. Semte "Unkapanı" denilmesinin sebebi ise, İstanbul'a tahıl getiren gemilerin yüklerini Unkapanı'na boşaltmalarıdır. İstanbul'a gelen zahire, yiyecek ve diğer ihtiyaç maddelerinin ölçümünün ekspertizinin, fiyatlandırmasının ve dağıtım işlemlerinin yapıldığı kapanların en önemlilerinden biri olan Un Kapanı'nın burada bulunması, giderek semtin de aynı adla anılmasına neden olmuştur. Hemen hemen her sokağında buğday ambarları, değirmenler ve firınlar bulunan semtin en büyük değirmen yapısı, Unkapanı

Değirmeni'dir.

Bizans döneminden beri Unkapanı bölgesi buğday ticaretinin yapıldı $\breve{g}_{1}$ yer olarak

Resim: 2

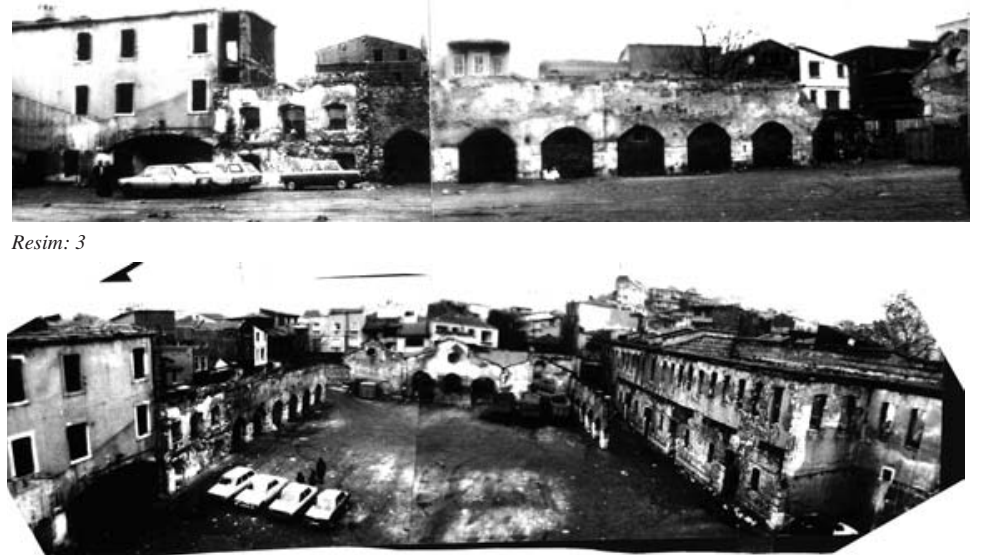

gelişmiş, İstanbul'un en önemli ticaret merkezlerinden biri olmuştur. Bu kadar çok buğday ticaretinin yapıldı $\breve{g}$ Unkapanı'nda birçok değirmen ve fırın kurulmuştur. 1840'lı y1llara kadar İstanbul'da çoğunlukla rüzgar, su ve at ile çalışan değirmenler kullanılmışken, bu yüzyllın sonunda bu değirmenler yerlerini buharla ve elektrikle çalışan yeni tesislere bırakmışlardır. Bu büyük tesislerden biri de Unkapanı'nda kurulmuş olan “Unkapanı Değirmeni”dir (Sakaoğlu, 1994).

19. yüzyılın sonlarında İstanbul'da buhar enerjisiyle çalışan altı değirmen olduğu ve bu yapıların Paşalimanı, Kasımpaşa, Göksu, Ayvansaray ve Unkapanı'nda bulunduğu bilinmektedir. Unkapanı'nda iki değirmen bulunmaktadır: Corpi ve Unkapanı Değirmeni (Müller-Wiener, 1998). Bugün altı değirmenden sadece üç tanesi, Paşalimanı, Kasımpaşa ve Unkapanı Değirmeni ayakta kalmıştır. İstanbul'un en büyük değirmenlerinden biri olan Paşalimanı Değirmeni, 1913-1915 sanayi sayımına göre 1858 yılında kurulmuş, 1940 yılından itibaren değirmen işlevini kaybetmiştir (Divan, 1984). Kasımpaşa Değirmeni ise; 1852 tarihinde yapım izni çıkmış, 1900'lerin başında elektrik motorları ile çalışmaya başlamıştır. Bu nedenle yeni teknolojiye uyum sağlayan ilk değirmenlerden biridir. 1982 yılından itibaren üretimine son verilen değirmen binası bugün de kullanılmamaktadır (Ezgeç, 1998).

Unkapanı Değirmeni'nin, 1870 yılında yapım izni çıkmış; önceleri özel kişiye aitken, daha sonra devlet tarafından el konularak bir süre işletilmiştir. Değirmenin içerisinde kullanılan tüm makineler İngiltere'den getirtilmiştir. Birçok binadan oluşan ve büyük bir komplekse sahip olan Unkapanı 

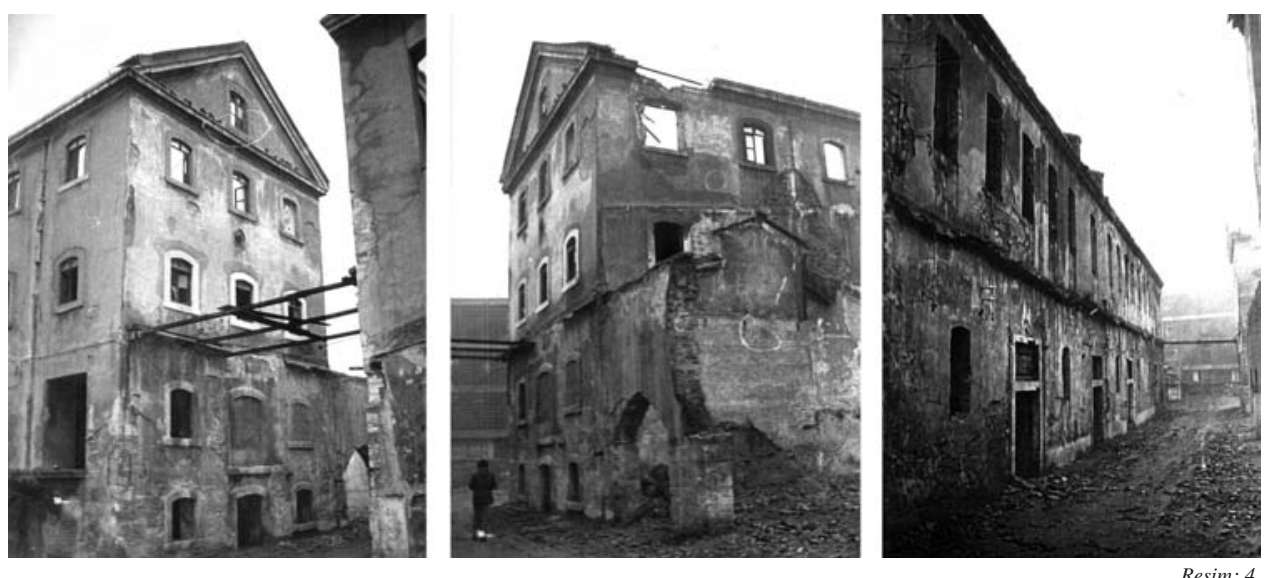

Değirmeni'nin iki bacası bulunmaktadır. 19. yüzyılın sonlarına ait İstanbul silueti fotoğrafında değirmen binası, ek binalar ve bacalar açıkça görülmektedir.

1940 yılında devlet tarafından satılmış ve yeniden özel mülkiyet tarafından işletilmiştir. Bu dönemde bir yangın geçirmiş ve daha sonra Umumi Mağazalar'a satılmıştır. İstanbul Manifaturacılar Çarşısı yapımı sırasında, kompleksin ana binası olan değirmen binası yıkılmıştır. 1980'li yıllarda yapılan ihale ile Unkapanı Değirmeni’ni, Ticaret Borsası satın almış ve otopark olarak kiraya vermiştir (Divan, 1984).

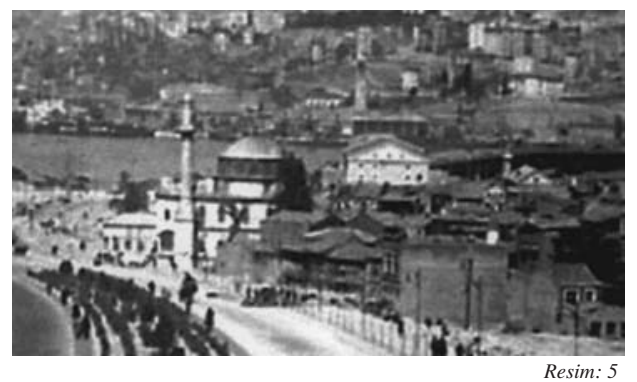

Unkapanı Değirmeni konum olarak denize oldukça yakın bir bölgede kurulmuş ve içinde kurulan sistem ile değirmenin bir kapısından giren un, diğer kapıdan ekmek olarak çıkmak üzere programlanmıştır. 1940’lı yıllarda Atatürk Köprüsü'nün inşa edildiği dönemde çekilen fotoğrafta değirmen binasının yıkılmadan önceki son hali açıkça görülmektedir (Resim 5). 1970 y1lı tarihli fotoğraflarda ise değirmen kompleksi içindeki diğer binaların yıkılmadan önceki mevcut durumları hakkında bilgi sahibi olunmaktadır.

\section{Konum ve çevre özellikleri}

Unkapanı adıyla anılan semt, Eminönü ilçesi sınırları içerisinde bulunmaktadır. Unkapanı Değirmeni, Eminönü ilçesi sınırları içinde kalan, Yavuz Sinan Mahallesi, 515 nolu ada üzerinde yer almaktadır. Kuzeybatısında İ.M.Ç. blokları ile, batısında Hoca Halil Camisi'nin bulunduğu değirmenin, kuzeydoğusunda Unkapanı Değirmeni sokağı, güney doğusunda ise Yeni Hayat Sokağı bulunmaktadır.

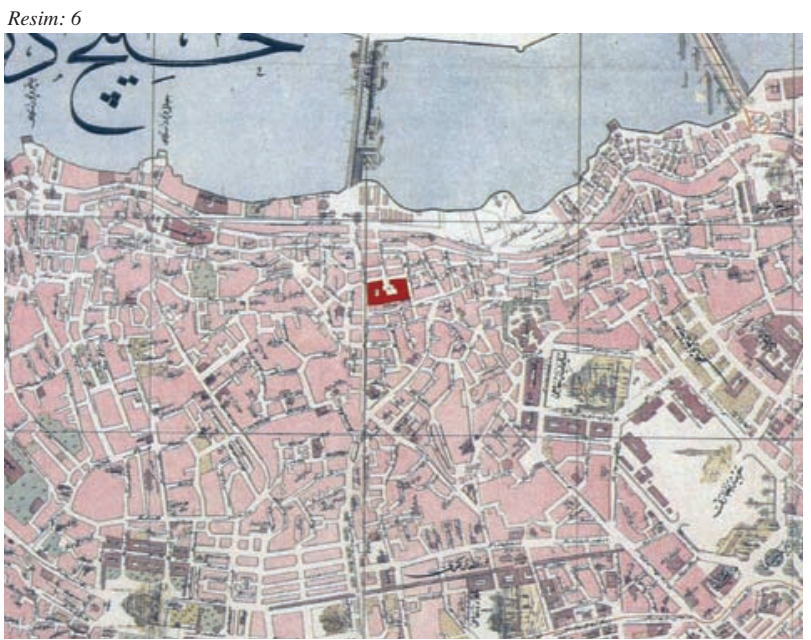

Unkapani

Değirmeni, 1970

(Hüsrev Tayla)

Resim: 5

Unkapanı Değirmeni, 1940'lı yıllar

Resim: 6

$1900^{\prime}$ lerin başında Unkapanı Değirmeni Resim: 7

1912 tarihli Alman Mavisi Sehir Haritası'nda Unkapanı Değirmeni Resim: 8 J. Pervititch haritasinda Unkapanı Değirmeni (1930)

Resim: 9

Ekrem Hakkı Ayverdi haritasında değirmen (1900) 

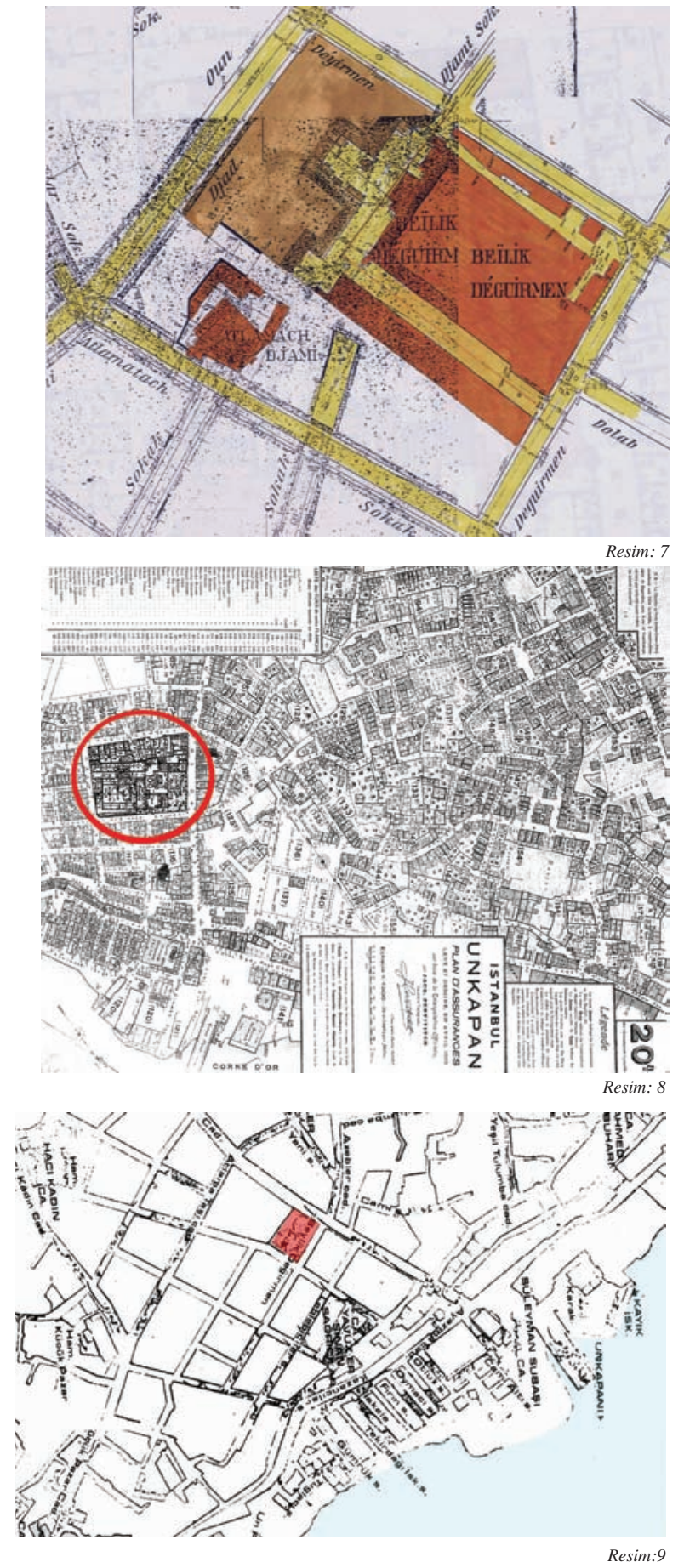

Unkapanı Değirmeni'ne ait bulunan en eski dökümanlar, 1912 tarihli Alman Mavisi şehir haritası ve aynı dönemde Ekrem Hakkı Ayverdi tarafından yayınlanan haritalardır (Resim 6-7-9). Her iki haritada da yapının planı ayrıntılı olarak belirtilmiş ve "Beylik Değirmeni" olarak adlandırılmıștır. 1930 tarihli J. Pervititch haritalarında da Unkapanı Değirmeni görülmekte, burada değirmenden "Belediye Değirmeni" olarak söz edilmektedir (Resim 8).

\section{Mimari özellikler}

1870'li yıllarda Unkapanı Değirmeni'nin dört giriş kapısı bulunmaktaydı. Unkapanı Limanı'na gelen buğday, değirmeninin kuzeydoğu cephesine bakan kapıdan (K02) içeri girmekte ve içeride bulunan dekovil aksıyla taşınarak depolara getirilmekteydi (Resim 10). 19. yüzyılın sonu fotoğrafı, J. Pervititch ve şehir haritalarından alınan bilgilere göre Unkapanı Değirmeni kompleksinde, değirmen binası, depo binaları, fırın, yatakhane binası, dükkanlar, bacalar ve sarnıç bulunmaktaydı.

Kompleks içindeki esas değirmen binası 19. yüzyıl sonlarında İstanbul'da yapılan ve buharla çalışan diğer değirmen yapılarında olduğu gibi, beş katlı, beşik çatılı ve üçgen alınlıklıdır. Bu dönemlerde yapılan Kasımpaşa Değirmeni ve Paşalimanı Değirmeni de incelendiğinde; Unkapanı Değirmeni ile benzer mimari özelliklere sahip oldukları görülmektedir (Resim 11). Genellikle duvarları almaşık tuğla duvar, döşeme olarak demir takviyeli ahşap kirişleme kullanılmıştır (I).

Bu değirmen binasının yanında 2 ve 4 katlı iki adet ek yapı ve bir firın binası bulunmaktadır. Depo binası olarak kullanılan dört katlı yapıda değirmen binası gibi demir takviyeli ahşap kirişlemeye sahip, almaşık tuğla duvarlı, üçgen alınlıklı ve beşik çatılı bir binadır. İki katlı depo binası da aynı yapısal özelliklere sahip olmasının yanında, ayrıca çelik kolonlarla taşınan asma katı bulunmaktadır. 


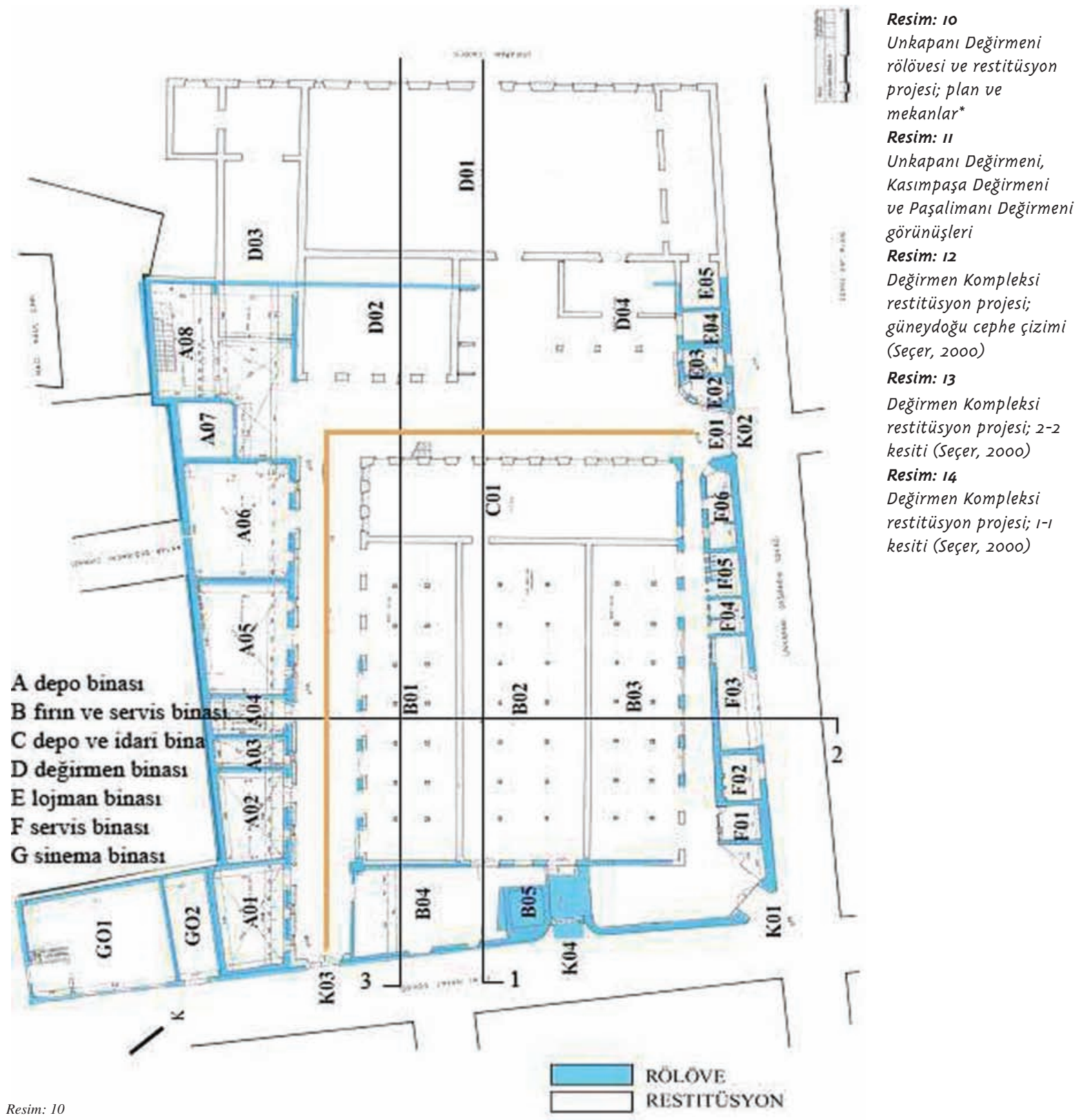

Tek katlı fırın binası, metal çatılı, çelik kolonlu, almaşık tuğla duvarlıdır.

Bu bina, kuzeydoğu-güneybatı doğrultusunda uzanan, üç bölümden oluşan, kare şeklinde yaklaşık 1000 metrekare büyüklüğünde bir binadır. Üç bölümden oluşan binanın orta bölümü depo ve servis binalarıyla, kenarda kalan bölümleri ise avluyla bağlantılıdır. Fırın binasında bir adet baca bulunmakta ve burada pişirme işleminin yapıldı̆̆ 1 tahmin edilmektedir.

Depo binaları iki tanedir. Kompleksin güneydoğusunda kalan iki katlı binanın zemin katı depo, üst katı yatakhane olarak kullanılmaktadır. Bu binada sarnıç ve bir baca bulunmaktadır. 1930 tarihli J. Pervititch haritasında baca ve sarnıç açıkça görülebilmektedir. Depo ve yatakhane binasının önünden üstü sundurmayla örtülmüş dekovil hattı geçmekte, öğütülen unun, bu dekovil
Resim: 10

anı Değirmen stitüsyon

Unkapanı Değirmeni, Kasımpaşa Değirmeni ve Paşalimanı Değirmeni nüşleri

Değirmen Kompleks restitüsyon projesi; güneydoğu cephe f̧izimi restitüsyon projesi; 1-1 kesiti (Seçer, 2000) 

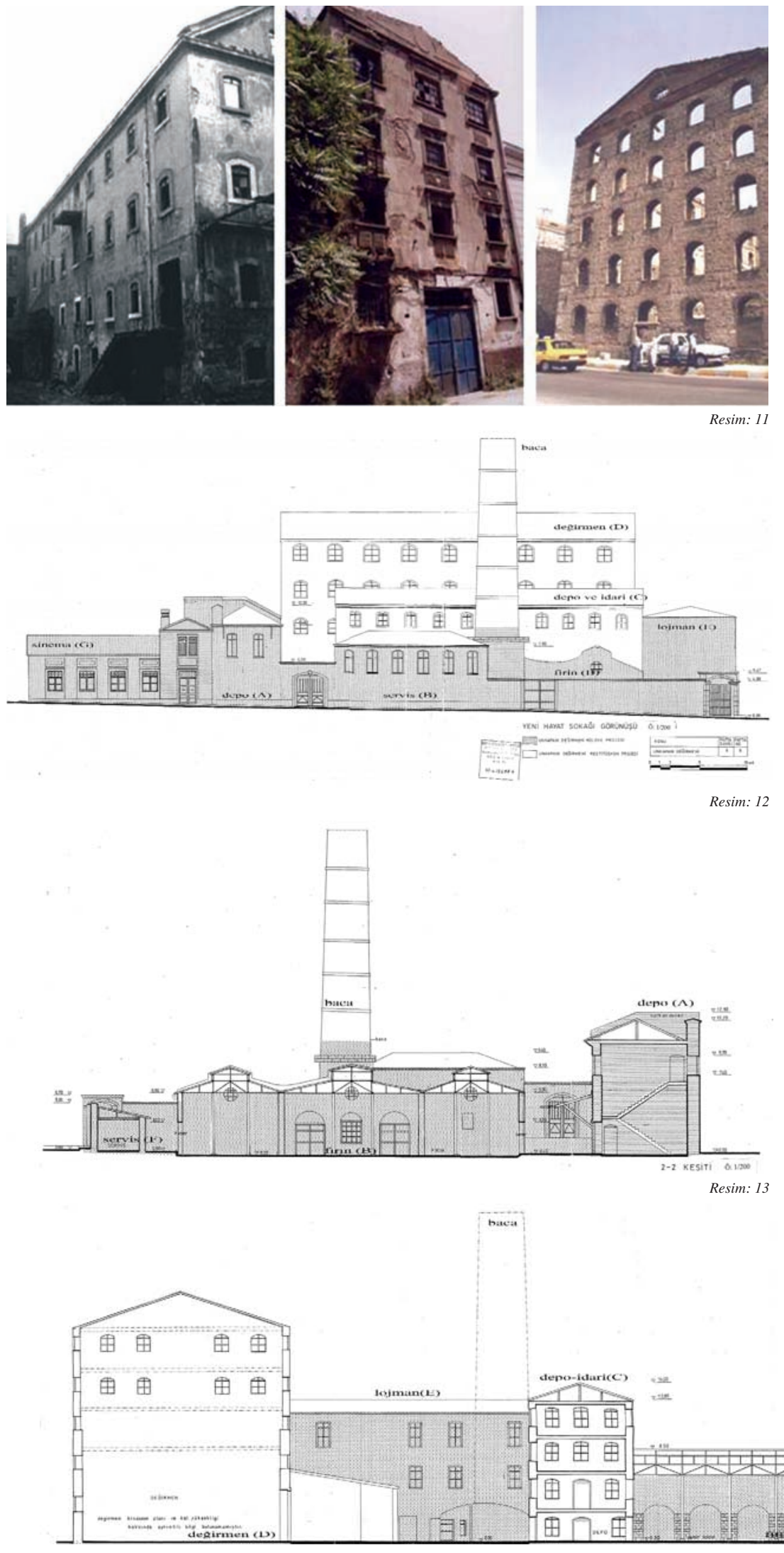

hattı sayesinde taşınırak depolandığ 1 sanılmaktadır. Diğer depo binası, fırın binasının yanında bulunan depo ve idare olarak kullanılan binadır. Zemin katı depo üst katları idare olarak kullanılan bina dikdörtgen bir plana sahiptir.

İki katlı yatakhane binası volta döşemeli, beşik çatılı, almaşık tuğla duvarlıdır. Bu binada idari bölümler, tek katlı buğday siloları ve dükkanlar bulunmaktadır. Unkapanı Değirmeni'ne sonradan eklenen bir de lojman binası bulunmaktadır.

Üç katlı beşik çatılı lojman binasının cephesi Unkapanı Değirmeni Sokağı'na bakmaktadır. Binanın zemin katında değirmenin ana giriş kapılarından biri bulunmaktadır.

\section{Mevcut durum ve bozulmalar}

Günümüzde Unkapanı Değirmeni'nde bozulma durumuna bakıldığında, tümüyle yok olan bölümlerin yanı sıra, mekan, cephe, strüktür ve malzemede görülen bozulmalar saptanmıştır. Değirmen kompleksinde bulunan yapılardan günümüze sadece servis binasının tamamı, fırın binasının üç duvarı, depo ve yatakhane binasının duvarları ile lojman binasının bir bölümü gelebilmiştir. 


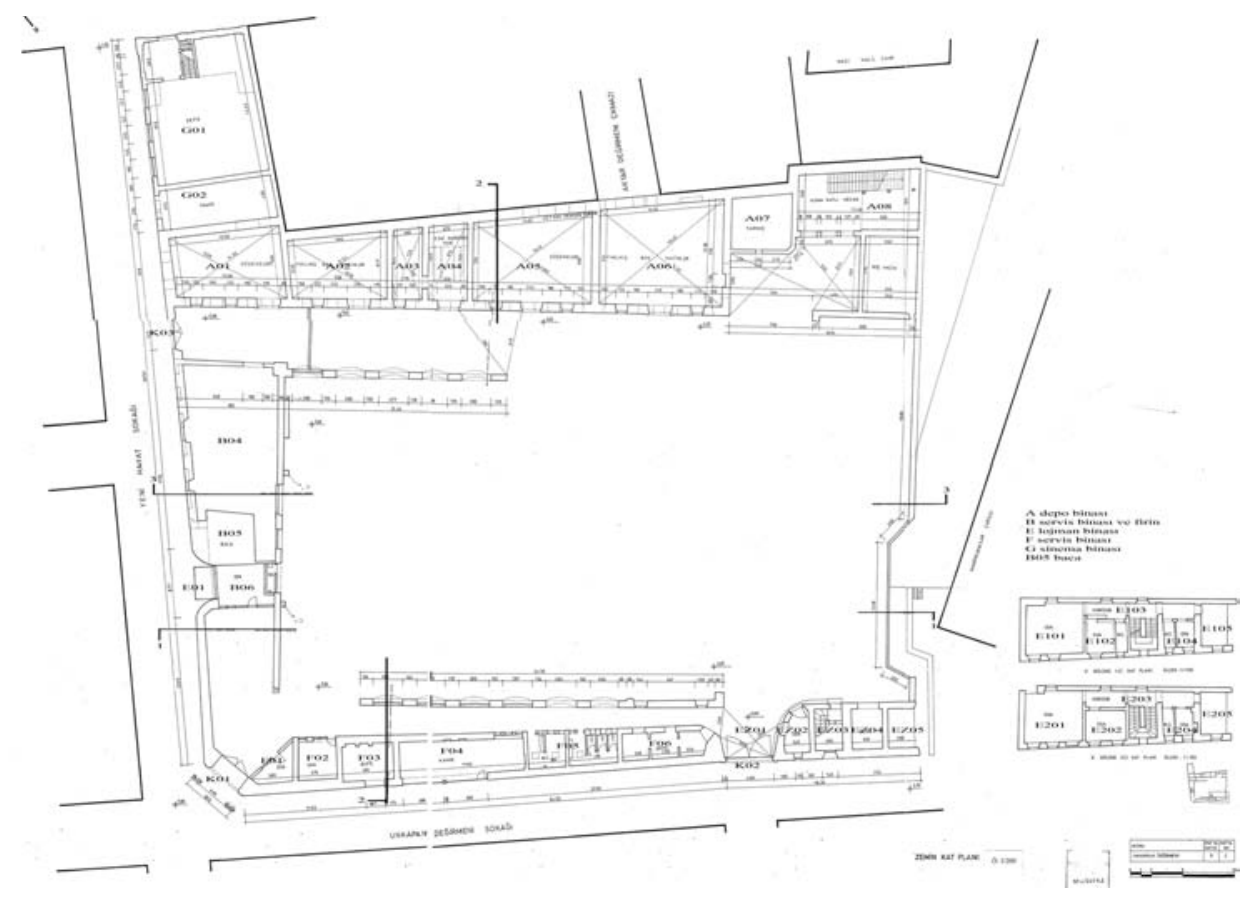

Resim: 15

Unkapanı Değirmeni

Rölöve Projesi; plan

(Seçer, 2000)

Resim: 16

Unkapanı Değirmeni

rölövesi; 2-2 kesidi

(Sesfer, 2000)

Resim: 17

Unkapanı Değirmeni

rölövesi; 3-3 kesiti

(Seçer, 2000)

Resim: 18

Değirmen kompleksinde-

ki A depo binasinin

görünüşü (1982) (2000)

Resim: 19

Unkapanı Değirmeni

rölövesi; ו- kesiti

Resim: 20

Unkapanı Değirmeni

yıkılan depo, idare (C)

ve lojman binasi (E)

(1970)

Resim: 15

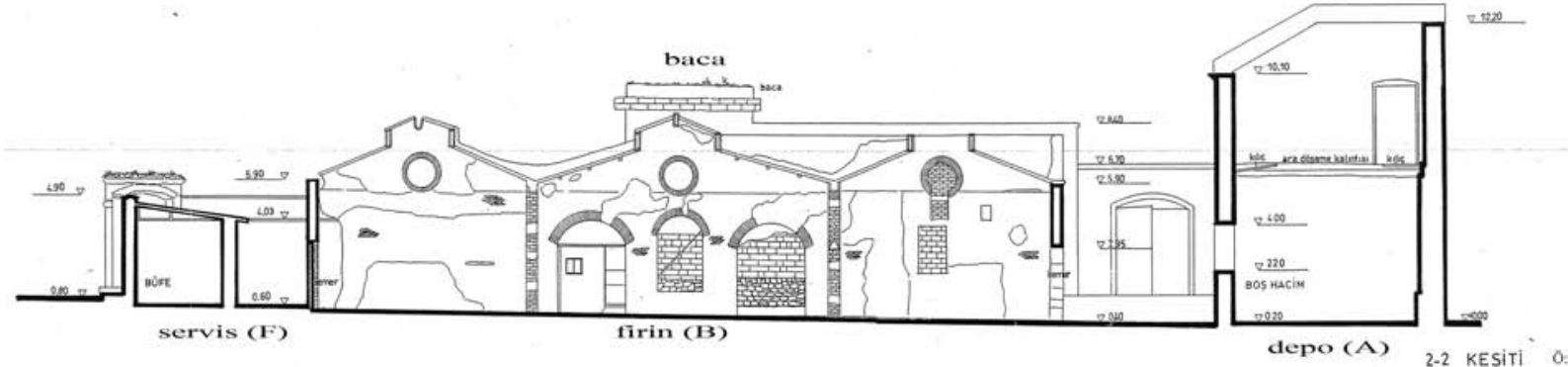

Resim: 16

Unkapanı Değirmeni kompleksinde bulunan esas değirmen binası günümüzde mevcut değildir. $\mathrm{Bu}$ binanın bulunduğu yerde bugün İstanbul Manifaturacılar Çarşısı Blokları bulunmaktadır. Bir bölümü ayakta kalmayı başarmış fırın binasının güneydoğu duvarının tamamı ile, güneybatı ve kuzeydoğu duvarlarının bir bölümü mevcuttur. Binanın diğer duvarları, döşemesi ve çatı örtüsü yok olmuştur. Çoğu yok olmuş depo binalarından yalnızca kuzeybatı cephesindeki binanın duvarları ayaktadır. Değirmen kompleksinin kuzeyinde bulunan üç katlı lojman binasının kuzeybatı cephesi, İstanbul

Manifaturacılar Çarşısı Blokları yapımı sırasında yıkılmışsır. Günümüze kadar oldukça iyi halde korunarak gelmiş bulunan sinema binasının cephesindeki sıvalar dökülmüş, kapı ve pencere doğramaları yok olmuştur.

Unkapanı Değirmeni kompleksindeki tüm binaların cephe sıvaları, kapı ve pencere doğramaları ve döşemeleri günümüzde bulunmamaktadır.

Değirmenin iki bacasından biri tamamen, diğerinin ise bir kısmı yıkılmıştır.

Değirmen kompleksindeki binaların tüm bozulma durumları bir bozulma tablosu 


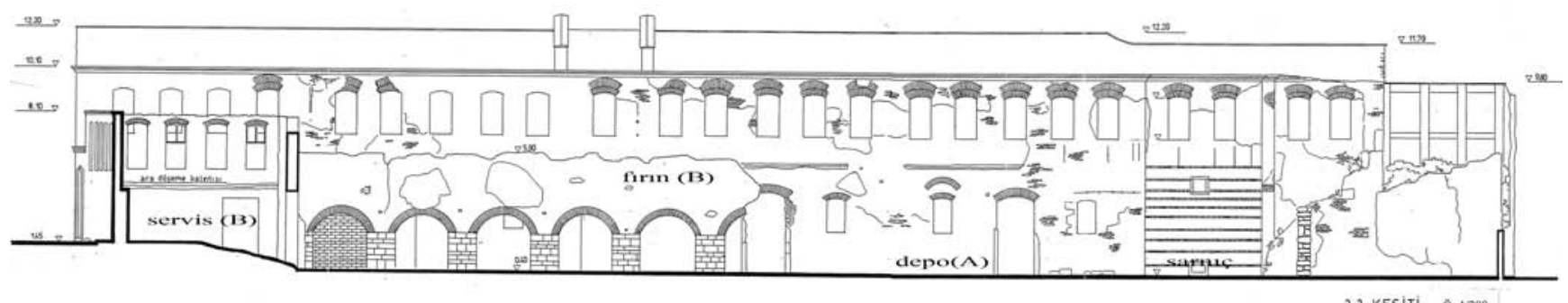

3-3 KESITI 0: 1/200

Resim: 17
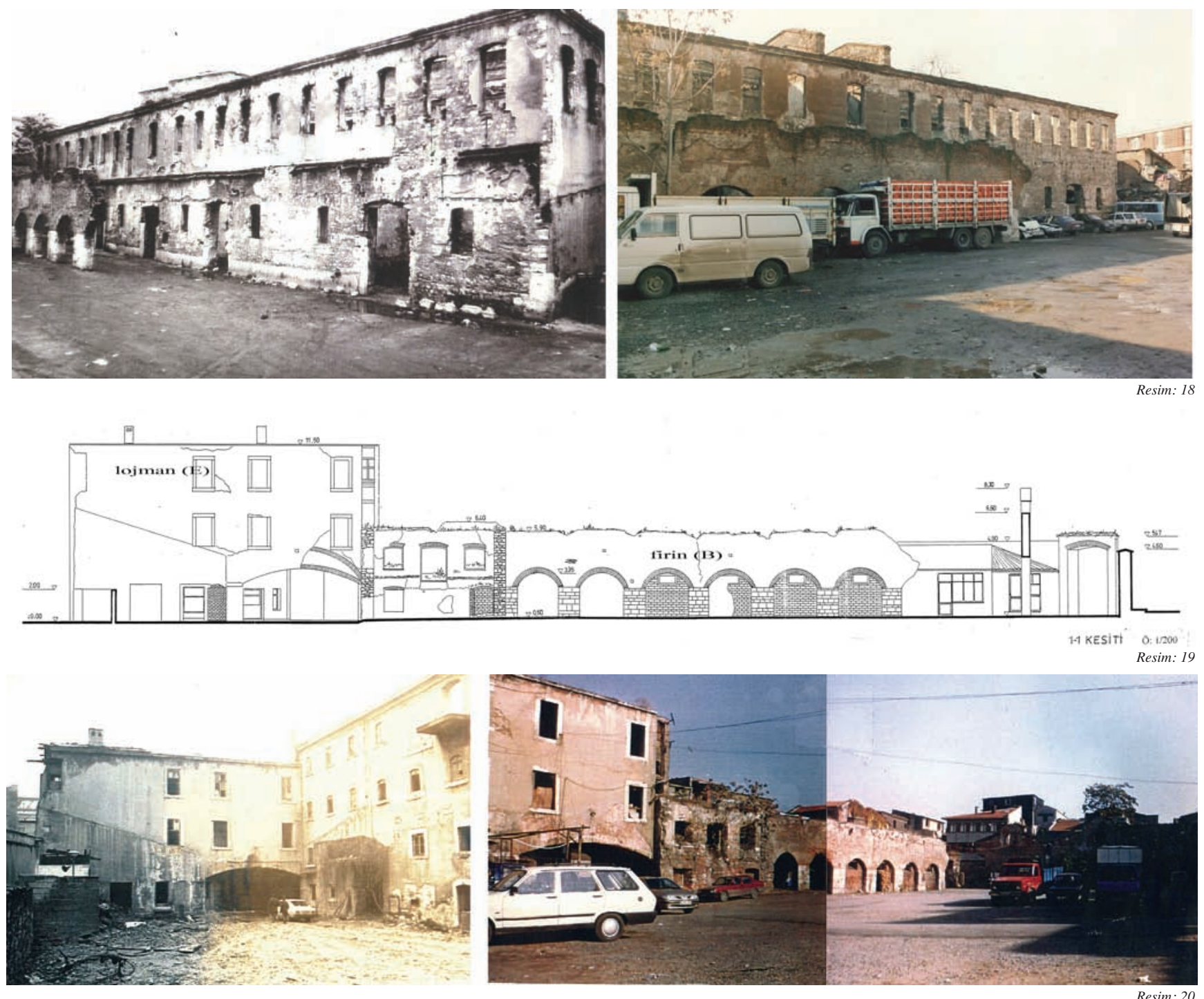

yapılarak belirtilmiş; bu tabloda özgün kısımlar, yok olanlar, ek ve değişiklikler ve diğer tahribatlar olarak her bina için bozulma durumu incelenmiştir.
Unkapanı Değirmeni koruma ve yeniden kullanım önerileri

Tarihi endüstri yapılarının işlev dönüşümü çalışmalarında binanın mevcut doku içindeki yeri, ekonomik, sosyal ve çevresel 


\section{UNKAPANI DEĞİRMENİ BOZULMA TABLOSU}

\begin{tabular}{|c|c|c|c|c|}
\hline YER & $\begin{array}{l}\text { ÖZGÜN } \\
\text { KISIMLAR }\end{array}$ & YOKOLANLAR & $\begin{array}{c}\text { EK VE } \\
\text { DEĞİŞ்LİKLER }\end{array}$ & $\begin{array}{c}\text { DİĞER } \\
\text { TAHRİBATLAR }\end{array}$ \\
\hline $\begin{array}{l}\text { PO } \\
\text { NASI I }\end{array}$ & $\begin{array}{l}\text { Duvarlar } \\
\text { Kapı ve pencere } \\
\text { boşluğu ve söveleri }\end{array}$ & $\begin{array}{l}\text { Döşeme Malzemesi } \\
\text { Kapı ve pencere } \\
\text { doğraması }\end{array}$ & $\begin{array}{l}\text { Üstü ve ön cephesi } \\
\text { örtülerek kapatılmış }\end{array}$ & $\begin{array}{l}\text { Ön cephesine ve } \\
\text { kap iya takılan } \\
\text { kepenk }\end{array}$ \\
\hline
\end{tabular}

\begin{tabular}{|c|c|}
\hline $\begin{array}{l}\text { DEPO } \\
\text { BİNASI II }\end{array}$ & \\
\hline $\begin{array}{l}\text { FIRIN } \\
\text { BİNASI }\end{array}$ & $\begin{array}{l}\text { Güneydoğu duvarı } \\
\text { Kapı ve pencere } \\
\text { boşluğu }\end{array}$ \\
\hline
\end{tabular}

Günümüzde II depo binası tamamen yıkılmıştır.

\section{DEĞIIRMEN}

BINASI

\begin{tabular}{l|l} 
LOJMAN & Duvarlar \\
BiNASI & Kapı ve pencere \\
& boşluğu ve sövesi \\
& Merdiven \\
\hline
\end{tabular}

\begin{tabular}{|l|l}
\hline SERVIS & $\begin{array}{l}\text { Duvarlar } \\
\text { Kapı ve pencere } \\
\text { biNASI }\end{array}$ \\
& $\begin{array}{l}\text { Duşuğu ve söveleri ve } \\
\text { döșeme }\end{array}$
\end{tabular}

\section{SIINEMA}

BİNASI

\section{Çatı örtüsü}

Kap1 ve pencere

doğramas1

\section{Diğer duvarları \\ Çatı örtüsü ve döşeme}

Kapı ve pencere doğramasi

Günümüzde

değirmen binası

tamamen yıkılmışıtır.

Döşeme Malzemesi

Kapı doğraması

Kapı doğraması

değ işti rilmiştir.
Ön cephesine saçak yapılmıştır.
Güney doğu duvarında w.c. bölümü eklenmiş

bulunan kapı ve

pencereler örülmüş

Tablo: 1

durumları sorunun bir bütün olarak ele alınmasını zorunlu kılmaktadır.

(Alttnoluk 2000)

Tarihi endüstri yapılarının yeni kullanımına ilişkin çalışma yapılırken, göze ilk çarpan binanın özgün kimliğinin mümkün olduğunca korunması ve o binaya ait özelliklerin vurgulanmış olmasıdır. Yeni kullanımlara açılan bu binalarda binaların eski işleyişinin ve üretiminin panolarla kullanıcıya sunulması gerekmektedir. Bu yapılar alışveriş mekanları, sanat galerileri, çok amaçlı salonlar (geniş açıklkklar ve ağır yük taşıyabilecek yapısal düzenlemelere sahip oluşlarından yararlanilarak) ve konut (açık kat düzenlemeleri ve yüksek tavanlarından yararlanlarak) olarak kullanılabilmektedir.
Tablo: I

Unkapanı Değirmeni bozulma durumu* 


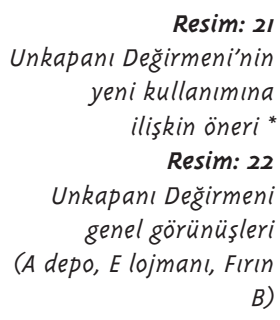

B)
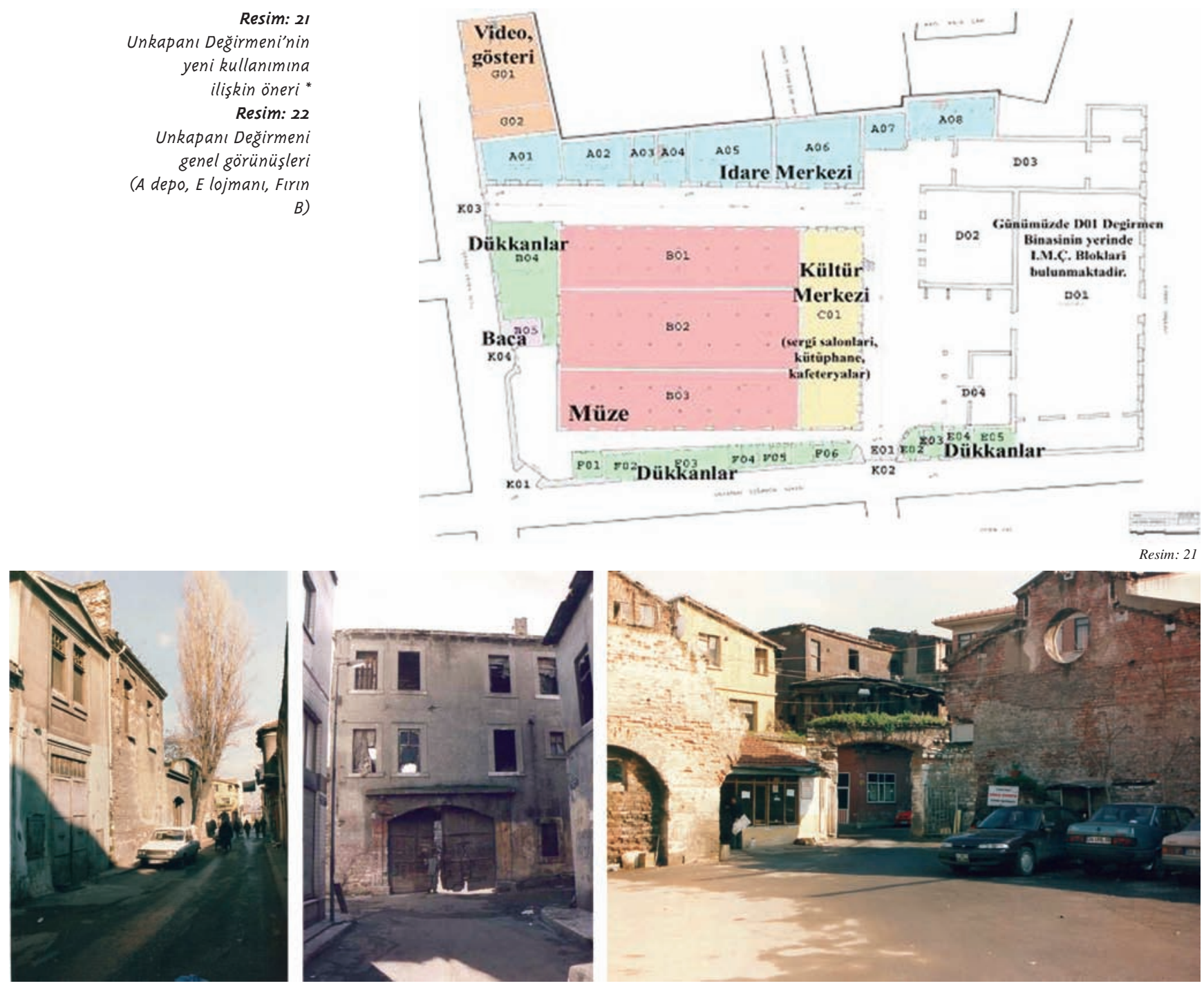

Resim: 23

(Ökem, 2000) Günümüzde dünyada da işlevini kaybetmiş olan değirmen yapıları otel, büro binası, mobilya mağazası, lokanta, tiyatro ve konut gibi çok amaçlı olarak kullanılmaktadır.

Unkapanı semtinin şehir merkezinde olması ve Taksim, Fatih ve Zeyrek gibi semtlere yakınlığı nedeniyle Unkapanı Değirmeni'nin kültür ve iş merkezi olarak değerlendirilmesi uygun

2 seçer, Füsun, 2002. istanbul'daki Osmanlı Dönemi Değirmenlerinin Mimari Açıdan Incelenmesi Ve Unkapanı Değirmeni'nin Günümüz sartlarında Değerlendirilmesi, MSÜ Fen Bilimleri Enstitüsü Yüksek Lisans Tezi görülmüş̧tür. Yapının çevrede bulunan okullara ve iş merkezlerine olan yakınlığ1, yeni kullanıma ilişkin önerilerde bulunurken etkili olmuştur. Cepheleri özgün olarak korunan yapının içinde, yeni işlevin gereği olan bazı değişiklikler ve ekler yapılması kaçınılmazdır.

Günümüzde Unkapanı Değirmeni için Yapı Merkezi tarafından Unkapanı Borsa-Kültür ve İş Merkezi Projesi adı altında bir proje hazırlanmış ve projenin uygulamasına başlanmıştır(2).

\section{Sonuç}

Endüstri yapıları dönemin teknolojisini ve ekonomik düzenini aktarması, toplumun yaşamını yansıtması açısından 


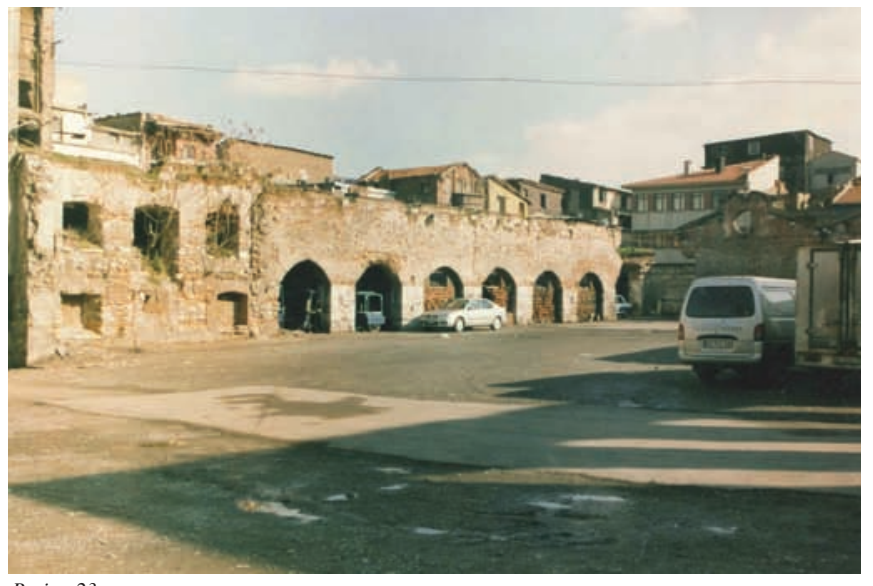

Resim: 23

büyük bir öneme sahiptir. Zamanla fonksiyonunu yitiren bu yapılar boş ve bakımsız kalarak hızla tahrip olmuşlardır. Günümüzde harap olan endüstri yapılarının, zaman içinde hasar görmesini önlemek ve binaların mümkün olduğunca korunmasına çalışmak gerekmektedir. $\mathrm{Bu}$ amaçla, endüstri mirası kapsamında bulunan yapiların tespit, tescil ve belgeleme çalışmalarını içeren detaylı araştırmaları yapılmalı ve rölöveleri hazırlanmalıdır. Yapılar çok iyi tanınmalı, sonradan eklenen kısımlar belirlenip tarihlendirilerek dönem analizleri oluşturulmalı ve bütün bu çalışmalar belgelere dayandırılarak yapılmalıdır.

Unkapanı Değirmeni'nin zaman içinde daha çok hasar görmesini önlemek için güncel bir işlevle değerlendirilmesi ve yaşatılması gerekmektedir. Daha önce de vurgulandığı gibi, endüstri yapılarından, bugün hala orjinal işlevini sürdüreni yok denecek kadar azdır. Aynı şekilde, değirmenler de bugün işlevlerini kaybetmiş ve yerlerini modern fabrikalar almıştır. Bu tür yapıların yaşayabilmeleri için restore edilmeleri, ne şekilde

değerlendirilmeleri gerektiği düşünülmeli, yapısal onarım ve sağlamlaştırmaların yanı sıra, uygun

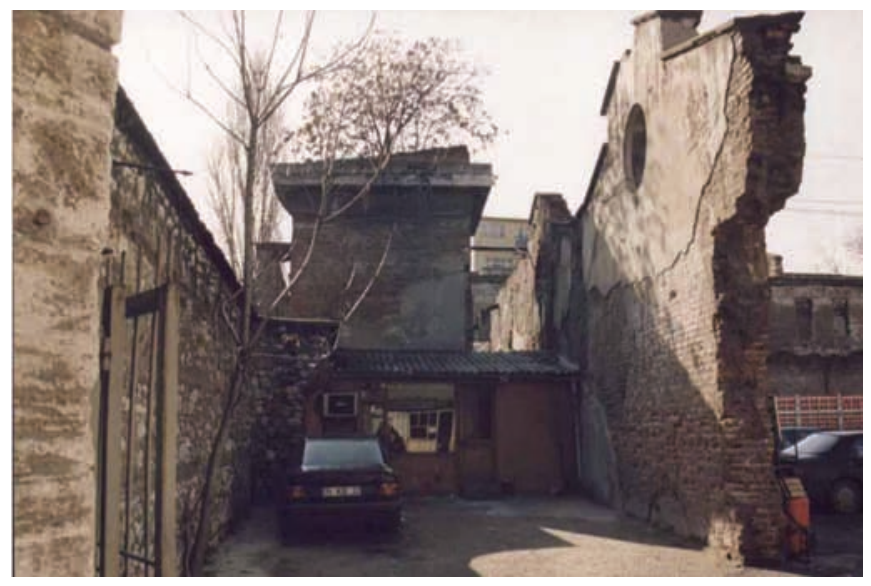

bir işlev ile sürekliliklerinin sağlanması da Resim:23 gerekmektedir. Yapılacak restorasyon çalışmalarında, yapılara müdahale en az Unkapanı Değirmeni $B$ firın binası ve baca görünüşü şekilde olmalı, yapılar hakkında bilgi toplanmalı, belgeler bulunmalı ve bu belgeler çok iyi değerlendirildikten sonra belgeye dayalı restitüsyonuna sadık kalınarak restorasyon yöntemleri uygulanmalıdır. Sonuç olarak, Unkapanı Değirmeni kompleksinin mevcut doku içindeki yeri, sosyal ve çevresel verileri ele alındığında, kültür ve iş merkezi olarak işlev verilmesi önerilmiştir(3) ve günümüzde de Yapı Merkezi tarafından yürütülen restorasyon projesinde aynı şekilde işlevlendirildiği görülmüştür (2009) •

$64 \mid$ Sayı 7, Mayıs 2009

3 seçer, Füsun, 2002.

Istanbul'daki Osmanlı Dönemi Değirmenlerinin Mimari Açıdan incelenmesi ve Unkapanı Değirmeni'nin Günümüz şartlarında Değerlendirilmesi, MSÜ Fen Bilimleri Enstitüsü Yüksek Lisans Tezi 